Supplement of

\title{
Comparison of co-located refractory black carbon (rBC) and elemental carbon (EC) mass concentration measurements during field campaigns at several European sites
}

Rosaria E. Pileci et al.

Correspondence to: Robin L. Modini (robin.modini@psi.ch) and Martin Gysel-Beer (martin.gysel@psi.ch)

The copyright of individual parts of the supplement might differ from the CC BY 4.0 License. 


\section{Supplementary information (SI)}

\section{S1. Further details concerning the optical correction in thermal optical analysis (TOA)}

During TOA analysis a fraction of the OC can pyrolyze in the He step to form pyrolytic carbon (PC), which is thermally stable and only desorbs in the $\mathrm{O}_{2}$ step, thereby causing a charring artefact in the mutual quantification of OC and EC. To correct for this latter effect a laser at $658 \mathrm{~nm}$ can be used to monitor the light transmission through the loaded filter before and during the analysis. PC is strongly light absorbing, thus leading to a decrease of the transmission signal when it forms upon heating in the inert atmosphere. Later, in the oxidizing atmosphere, both PC and EC are released from the filter resulting in an increase of the transmission signal. The time at which the transmission equals again the initial pre-pyrolysis value is used to separate OC and EC, depending on whether the carbon evolved before or after this "split point", respectively. This thermal-optical transmittance (TOT) approach to correct for PC eliminates potential charring artefacts if the PC has the same mass-specific attenuation cross section as the atmospheric native EC (Yang and Yu, 2002), and if no other light-absorbing material evolves from the sample.

Instead of using light transmission, the charring correction can also be done with light reflectance (i.e., thermaloptical reflectance, TOR). EC values determined using TOT can be up to $30-70 \%$ lower than those determined with TOR (Karanasiou et al., 2015), because the evaporation of non-absorbing particulate matter during heating affects the reflectance to a greater extent than the transmission signal. Furthermore, high loadings of EC result in saturation effects of both optical signals, again to a greater extent for the reflection compared to the transmission method (Chiappini et al., 2014). These two effects result in better reproducibility and accuracy of the TOT based

\section{S2. Calculation of variability and bias}

The variability $\left(Q_{A V}\right)$ is defined as the relative standard deviation given by the $95 \%$ confidence limit, thus:

$$
Q_{A V}=\frac{n}{\sqrt{6}}\left[\max \left(\frac{R D_{i}}{T_{i}}\right)-\min \left(\frac{R D_{i}}{T_{i}}\right)\right]
$$

25 Where $\mathrm{RD}_{\mathrm{i}}=\mathrm{L}_{\mathrm{i}}-\mathrm{T}_{\mathrm{i}}$, with $\mathrm{L}_{\mathrm{i}}$ and $\mathrm{T}_{\mathrm{i}}$ representing the laboratory and expected concentrations, respectively.

The bias $\left(Q_{A B}\right)$ is defined as the median of the percentage of the ratio between $R_{i}$ and $T_{i}$

$$
\mathrm{Q}_{\mathrm{AB}}=\operatorname{median}\left[\frac{R \mathrm{D}_{\mathrm{i}}}{\mathrm{T}_{\mathrm{i}}} \%\right\rfloor
$$

\section{S3. The Cunningham slip correction}

The Cunningham slip correction factor, $\mathrm{C}_{\mathrm{C}}$, is used to account for non-continuum effects when calculating the

drag force on small particles. $C_{C}$ depends on the particle diameter, $D$, the mean free path of the surrounding gas, $\lambda$, and on the experimental coefficients $\alpha, \beta$ and $\gamma$ (Cunningham, 1910; Seinfeld and Pandis, 2006).

$$
C_{C}(D)=1+\frac{2 \lambda}{D}\left[\alpha+\beta \mathrm{e}^{-\frac{\gamma D}{\lambda}}\right]
$$

with $\alpha=1.257, \beta=0.4, \gamma=1.1, \lambda=6.510^{-8} \mathrm{~m}$ 
Hygroscopic growth affects the cut-off imposed by impactors operated at ambient RH. Here we provide simplified equations to calculate the volume equivalent diameter growth factor, $\mathrm{GF}$, of $\mathrm{BC}$-containing particles coated with a mixture of organic and inorganic matter. The GF is calculated using $\kappa$-Köhler theory (Petters and Kreidenweis, 2007):

$$
\mathrm{GF}(\mathrm{RH})=\left(1+\kappa_{\mathrm{tot}} \frac{\mathrm{RH}}{1-\mathrm{RH}}\right)^{1 / 3}
$$

40

where the hygroscopicity parameter of the mixed particle, $\kappa_{\text {tot }}$, is obtained with the ZSR-mixing rule written as (Petters and Kreidenweis, 2007):

$$
\kappa_{\text {tot }}=\varepsilon_{\mathrm{BC}} \kappa_{\mathrm{BC}}+\varepsilon_{\mathrm{org}} \kappa_{\mathrm{org}}+\varepsilon_{\text {inorg }} \kappa_{\text {inorg }}
$$

The hygroscopicity parameters $\kappa$ of $\mathrm{BC}$, organics and inorganics are assumed to be $0,0.1$ and 0.5 , respectively (Engelhart et al., 2012). The volume fraction, $\varepsilon_{\mathrm{x}}$, of compound class " $\mathrm{x}$ " in the particle can be calculated using:

$$
\varepsilon_{\mathrm{x}}=\frac{m_{\mathrm{x}}}{m_{\mathrm{tot}}} \frac{\rho_{\text {tot }}}{\rho_{\mathrm{x}}}
$$

where $m_{\mathrm{x}}$ is the mass of " $\mathrm{x}$ " in the particle, $m_{\mathrm{tot}}$ is the total particle mass. $\rho_{\mathrm{x}}$ is the material density of "x", which is assumed to be $1800 \mathrm{~kg} \mathrm{~m}^{-3}, 1200 \mathrm{~kg} \mathrm{~m}^{-3}$ and $1700 \mathrm{~kg} \mathrm{~m}^{-3}$ for BC, organics and inorganics, respectively. The mixed particle density, $\rho_{\text {tot }}$, is obtained with:

$$
\rho_{\text {tot }}=\frac{1}{\frac{m_{\mathrm{BC}}}{m_{\mathrm{tot}}} \rho_{\mathrm{BC}}+\frac{m_{\text {org }}}{m_{\text {tot }}} \rho_{\text {org }}+\frac{m_{\text {inorg }}}{m_{\text {tot }}} \rho_{\text {inorg }}}
$$

50 


\section{S5. Dryers and losses}

Differences in $m_{\mathrm{rBC}}$ and $m_{\mathrm{EC}}$ mass concentration can also come from differences in the losses of the respective sampling inlets. Particle losses can be caused by the presence of a dryer in the inlet line. The dryer technology offers different dryer types including diffusion and membrane dryers. Diffusion dryers use chemical adsorbents such as silica gel for the minimization of aerosol losses. When the aerosol passes through the tube, the silica adsorbs water vapor, therefore this chemical needs to be changed and regenerated on a regular basis. Membrane dryers are elastic tubes based on water vapor-permeable polytetrafluoroethylene (PTFE). Commercially available

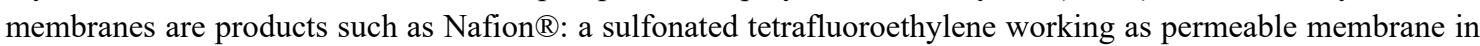
which water vapor molecules are transported.

In any case, particle losses by diffusion across the dryer should be accounted for in the data processing. This is done by calculating an equivalent tube length, which is longer than the actual dryer length (Wiedensohler et al., 2012).

In this work we calculate the diffusion losses when dryers were present in the inlet lines. A diffusion dryer was placed in front of the SP2 line during the Bologna campaign; while the EC line had none. The particle transmission efficiency of the diffusion dryer for a flow rate of $2 \mathrm{~L} \mathrm{~min}^{-1}$ was evaluated to be less than $10 \%$ on average on the size range of the SP2 measurements. Nafion dryers (model MD-700, Perma Pure) were set in front of the SP2s in the Melpitz and Cabauw campaigns. The diffusion losses through them were calculated with the hypothesis of laminar flow and were found to be negligible. The particle loss due to the presence of a dryer in the inlet line does

70 not seem to be the main reason of the $m_{\mathrm{rBC}}$ and $m_{\mathrm{EC} \_\mathrm{PM} 2.5}$ discrepancies for the campaigns of this study. For this reason we did not correct the $\mathrm{rBC}$ mass concentrations for this effect. 


\section{Tables SI}

Table S1: site, station code, coordinates, altitude and year/season of the field campaigns presented in this work.

\begin{tabular}{ccccc}
\hline Site (country) & Station code & Coordinates & Altitude & Year/season \\
\hline Palaiseau (FR) & Palaiseau & $48.713^{\circ} \mathrm{N} 2.208^{\circ} \mathrm{E}$ & 160 & $2010 /$ winter \\
& & & & $\begin{array}{c}\text { 2017/winter } \\
\text { and }\end{array}$ \\
Melpitz (DE) & Melpitz & $51^{\circ} 32^{\prime} \mathrm{N}, 12^{\circ} 56^{\prime} \mathrm{E}$ & 86 & $2015 /$ summer \\
& & & & $2016 /$ autumn \\
Cabauw (NE) & Cabauw & $51^{\circ} 58^{\prime} \mathrm{N}, 4^{\circ} 55^{\prime} \mathrm{E}$ & -0.7 & $2017 /$ summer \\
Bologna (IT) & Bologna & $44^{\circ} 31^{\prime} \mathrm{N}, 11^{\circ} 20^{\prime} \mathrm{E}$ & 39 & \\
\hline
\end{tabular}

75

Table S2: The first three columns show median, $10^{\text {th }}$ and $90^{\text {th }}$ percentiles of EC, TC and EC/TC filter loading. The last four columns show minima and maxima of EC and TC filter loadings for the field campaigns of this study.

\begin{tabular}{|c|c|c|c|c|c|c|c|}
\hline $\begin{array}{l}\text { Station } \\
\text { code }\end{array}$ & $\begin{array}{c}\mathrm{EC} \\
\text { filter loading } \\
\text { median } \\
\left(10^{\text {th }}, 90^{\text {th }}\right) \\
{\left[\mu \mathrm{g} \mathrm{cm}^{-2}\right]}\end{array}$ & $\begin{array}{c}\mathrm{TC} \\
\text { filter loading } \\
\text { median } \\
\left(10^{\text {th }}, 90^{\text {th }}\right) \\
{\left[\mu \mathrm{g} \mathrm{cm}^{-2}\right]}\end{array}$ & $\begin{array}{c}\mathrm{EC} / \mathrm{TC} \\
\text { filter } \\
\text { loading } \\
\text { median } \\
\left(10^{\text {th }}, 90^{\text {th }}\right) \\
{\left[\mu \mathrm{g} \mathrm{cm}^{-2}\right]}\end{array}$ & $\begin{array}{c}\text { Min EC } \\
\text { filter load } \\
\quad[\mu \mathrm{g} \\
\left.\mathrm{cm}^{-2}\right]\end{array}$ & $\begin{array}{c}\text { Max EC } \\
\text { filter load } \\
{\left[\mu \mathrm{g} \mathrm{cm}^{-2}\right]}\end{array}$ & $\begin{array}{c}\text { Min TC } \\
\text { filter load } \\
{[\mu \mathrm{g}} \\
\left.\mathrm{cm}^{-2}\right]\end{array}$ & $\begin{array}{c}\text { Max TC } \\
\text { filter } \\
\text { load } \\
{[\mu \mathrm{g}} \\
\left.\mathrm{cm}^{-2}\right]\end{array}$ \\
\hline Palaiseau & $\begin{array}{c}1.66 \\
(0.76,3.19)\end{array}$ & $\begin{array}{c}9.79 \\
(5.02,24.03)\end{array}$ & $\begin{array}{c}0.14 \\
(0.09, \\
0.30)\end{array}$ & 0.44 & 7.53 & 3.72 & 37.56 \\
\hline $\begin{array}{l}\text { Melpitz } \\
\text { winter }\end{array}$ & $\begin{array}{c}4.30 \\
(1.50,11.08)\end{array}$ & $\begin{array}{c}44.73 \\
(9.77 \\
110.72)\end{array}$ & $\begin{array}{l}0.11 \\
(0.09, \\
0.17)\end{array}$ & 0.93 & 12.53 & 5.45 & 115.03 \\
\hline $\begin{array}{l}\text { Melpitz } \\
\text { summer }\end{array}$ & $\begin{array}{c}0.90 \\
(0.48,1.43)\end{array}$ & $\begin{array}{c}12.47 \\
(6.93,19.08)\end{array}$ & $\begin{array}{c}0.08 \\
(0.05 \\
0.10)\end{array}$ & 0.25 & 2.30 & 4.76 & 24.43 \\
\hline Cabauw & $\begin{array}{c}1.47 \\
(0.71,2.34)\end{array}$ & $\begin{array}{c}6.87 \\
(3.78,14.95)\end{array}$ & $\begin{array}{l}0.18 \\
(0.12, \\
0.29)\end{array}$ & 0.48 & 3.44 & 2.92 & 19.10 \\
\hline Bologna & $\begin{array}{c}2.49 \\
(1.84,2.66)\end{array}$ & $\begin{array}{c}15.50 \\
(13.20 \\
17.72)\end{array}$ & $\begin{array}{c}0.16 \\
(0.11 \\
0.19)\end{array}$ & 1.63 & 2.74 & 12.46 & 18.42 \\
\hline
\end{tabular}


80 Table S3: In this table the aerodynamic particle diameter $D_{\text {aero }}$ corresponding to the upper SP2 cut-off, which depends on the $\mathrm{BC}$ mass equivalent diameter, $D_{\mathrm{ve}}$ (calculating starting from the $\mathrm{BC}$ core mass equivalent diameter, $D_{\mathrm{rBC}}$, knowing the particle mixing state), is given for different extreme hypotheses concerning particle shape $(\chi)$, mixing state and relative humidity $(\mathrm{RH})$. The calculations are made with the hypothesis of fixed density of BC core $\rho_{\mathrm{rBC}}=1800 \mathrm{~kg} \mathrm{~m}^{-3}$ and with the hypothesis of coating made by half organic material with $\kappa_{\text {org }}=0.1$ and $\rho_{\text {org }}=1200 \mathrm{~kg} \mathrm{~m}^{-3}$ and half inorganic material with $\kappa_{\text {inorg }}=0.5$ and $\rho_{\text {inorg }}=1700 \mathrm{~kg} \mathrm{~m}^{-3}$. From these hypothesis and knowing the ratio between the mass of the coating material, $m_{\text {coat }}$ and the mass of the BC core, $m_{\mathrm{rBC}}$, the total particle density, $\rho_{\mathrm{P}}$, can be calculated. The mixing state of the last example particle is constrained with SP2 measurements during the Melpitz winter campaign.

\begin{tabular}{|c|c|c|c|c|c|c|c|c|c|c|c|}
\hline & $\begin{array}{l}D_{\mathrm{rBC}} \\
{[\mathrm{nm}]}\end{array}$ & $\begin{array}{c}\rho_{\mathrm{P}} \\
{\left[\mathrm{kg} \mathrm{m}^{-3}\right]}\end{array}$ & $\kappa_{\text {tot }}$ & $\begin{array}{c}D_{\mathrm{ve}} \\
{[\mathrm{nm}]} \\
\text { Dry }\end{array}$ & $\begin{array}{l}\mathrm{GF} \\
(\mathrm{RH}= \\
80 \%)\end{array}$ & $\begin{array}{l}D_{\mathrm{ve}}[\mathrm{nm}] \\
(\mathrm{RH}= \\
80 \%)\end{array}$ & $\begin{array}{c}\mathrm{GF} \\
(\mathrm{RH}= \\
95 \%)\end{array}$ & $\begin{array}{c}D_{\mathrm{ve}}[\mathrm{nm}] \\
(\mathrm{RH}= \\
95 \%)\end{array}$ & $\begin{array}{c}D_{\text {aero }} \\
{[\mathrm{nm}]} \\
\text { Dry }\end{array}$ & $\begin{array}{c}D_{\text {aero }} \\
{[\mathrm{nm}]} \\
(\mathrm{RH}= \\
80 \%) \\
\end{array}$ & $\begin{array}{r}D_{\text {aero }} \\
{[\mathrm{nm}]} \\
(\mathrm{RH}= \\
95 \%) \\
\end{array}$ \\
\hline $\begin{array}{l}\text { Fractal-like pure BC: } \\
\chi=2.4 \text { (Park et al., } \\
2003 \text { ) }\end{array}$ & 722.0 & 1800.0 & 0.0 & 722.0 & 1.0 & 722.0 & 1.0 & 722.0 & 625.3 & 625.3 & 625.3 \\
\hline Spherical pure BC: $\chi=$ & 722.0 & 1800.0 & 0.0 & 722.0 & 1.0 & 722.0 & 1.0 & 722.0 & 968.7 & 968.7 & 968.7 \\
\hline $\begin{array}{l}\text { Coated BC: } \chi=1, \\
m_{\text {coat }}=m_{\mathrm{rBC}}\end{array}$ & 722.0 & 1579.4 & 0.1 & 909.7 & 1.2 & 1063.1 & 1.6 & 1423.4 & 1143.2 & 1336.0 & 1788.8 \\
\hline $\begin{array}{l}\text { Coated BC: } \chi=1, \\
m_{\text {coat }}=6 m_{\mathrm{rBC}}\end{array}$ & 722.0 & 1452.2 & 0.2 & 1381.1 & 1.2 & 1722.4 & 1.8 & 2432.5 & 1664.4 & 2075.6 & 2931.3 \\
\hline $\begin{array}{l}\text { Coated BC with coating } \\
\text { as observed during the } \\
\text { Melpitz Winter } \\
\text { campaign: }\end{array}$ & 722.0 & 1505.2 & 0.2 & 1078.2 & 1.2 & 1310.4 & 1.7 & 1815.9 & 1322.8 & 1607.7 & 2227.9 \\
\hline $\begin{array}{l}\chi=1, m_{\text {coat }}=2.33 \\
{[0.99-3.17] m_{\mathrm{rBC}}}\end{array}$ & & & & & & & & & & & \\
\hline
\end{tabular}

90 
Table S4: AAE $(470,950)$ statistics for the campaigns in this study: median, geometric mean, $10^{\text {th }}$ and $90^{\text {th }}$ percentiles and number of data points.

\begin{tabular}{cccccc}
\hline & Palaiseau & Cabauw & $\begin{array}{c}\text { Melpitz } \\
\text { summer }\end{array}$ & $\begin{array}{c}\text { Melpitz } \\
\text { winter }\end{array}$ & Bologna \\
\hline AAE median $(10$, & $1.35(1.24$, & $1.05(0.97$, & $1.19(1.09$, & $1.40(1.28$, & $1.03(1.01$, \\
$90)$ & $1.53)$ & $1.12)$ & $1.26)$ & $1.50)$ & $1.07)$ \\
$\begin{array}{c}\text { AAE geometric } \\
\text { mean } \\
\text { \# points }\end{array}$ & 1.36 & 1.04 & 1.18 & 1.38 & 1.04 \\
\hline
\end{tabular}

95 Table S5: Summary of site name, country, SP2 calibration material, $\mathrm{m}_{\mathrm{EC}}$ cut-off and TOA thermal protocol, sampling period, site characteristics and geometric mean of the $m_{\mathrm{rBC}} / m_{\mathrm{EC}}$ ratio for all the data. *One data point

\begin{tabular}{|c|c|c|c|c|c|}
\hline & $\begin{array}{c}\text { SP2 } \\
\text { Calibration } \\
\text { Material }\end{array}$ & $\begin{array}{l}m_{E C} \text { cut-off/ } \\
\text { TOA Thermal } \\
\text { technique }\end{array}$ & $\begin{array}{c}\text { Site name, } \\
\text { country }\end{array}$ & $\begin{array}{c}\text { Season/year } \\
\text { and site } \\
\text { characteristics }\end{array}$ & $\begin{array}{c}m_{r B C} / m_{E C} \\
\text { median }\end{array}$ \\
\hline Palaiseau & $\begin{array}{l}\text { Fullerene } \\
\text { Soot }\end{array}$ & $\begin{array}{c}\mathrm{PM}_{2.5} / \\
\text { EUSAAR-2 }\end{array}$ & Palaiseau, France & $\begin{array}{c}\mathrm{Jan} / \mathrm{Feb} 2010 \\
\text { suburban } \\
\text { background }\end{array}$ & 1.20 \\
\hline Cabauw & $\begin{array}{l}\text { Fullerene } \\
\text { Soot }\end{array}$ & $\begin{array}{c}\text { PM }_{10} / \\
\text { EUSAAR-2 }\end{array}$ & $\begin{array}{l}\text { Cabauw, } \\
\text { Netherlands }\end{array}$ & $\begin{array}{c}\text { Oct } 2016 \\
\text { rural background }\end{array}$ & 0.53 \\
\hline Bologna & $\begin{array}{l}\text { Fullerene } \\
\text { Soot }\end{array}$ & $\begin{array}{c}\mathrm{PM}_{2.5} / \\
\text { EUSAAR-2 }\end{array}$ & Bologna, Italy & $\begin{array}{c}\text { July } 2017 \\
\text { urban } \\
\text { background }\end{array}$ & 0.65 \\
\hline Melpitz winter & $\begin{array}{l}\text { Fullerene } \\
\text { Soot }\end{array}$ & $\begin{array}{c}\mathrm{PM}_{2.5} / \\
\text { EUSAAR-2 }\end{array}$ & $\begin{array}{l}\text { Melpitz, } \\
\text { Germany }\end{array}$ & $\begin{array}{l}\text { Feb } 2017 \\
\text { rural background }\end{array}$ & 1.29 \\
\hline $\begin{array}{l}\text { Melpitz } \\
\text { summer }\end{array}$ & $\begin{array}{l}\text { Fullerene } \\
\text { Soot }\end{array}$ & $\begin{array}{c}\text { PM }_{2.5 /} \\
\text { EUSAAR-2 }\end{array}$ & $\begin{array}{l}\text { Melpitz, } \\
\text { Germany }\end{array}$ & $\begin{array}{l}\text { July } 2015 \\
\text { rural background }\end{array}$ & 0.97 \\
\hline $\begin{array}{l}\text { Zhang et al. } \\
\text { (2016) }\end{array}$ & $\begin{array}{l}\text { Fullerene } \\
\text { Soot }\end{array}$ & $\begin{array}{c}\mathrm{PM}_{2.5} / \\
\text { IMPROVE }\end{array}$ & $\begin{array}{c}\text { Fresno, } \\
\text { California, USA }\end{array}$ & $\begin{array}{c}\mathrm{Jan} / \mathrm{Feb} 2013 \\
\text { urban } \\
\text { background }\end{array}$ & 0.70 \\
\hline $\begin{array}{l}\text { Miyakawa et } \\
\text { al. (2016) }\end{array}$ & $\begin{array}{l}\text { Fullerene } \\
\text { Soot }\end{array}$ & $\begin{array}{c}\mathrm{PM}_{2.5} / \\
\text { IMPROVE-like }\end{array}$ & Yokosuka, Japan & $\begin{array}{c}\text { Summer } 2014 \\
\text { June } 17-27 \\
\text { urban }\end{array}$ & 1.07 \\
\hline $\begin{array}{l}\text { Sharma et al. } \\
\text { (2017) }\end{array}$ & $\begin{array}{l}\text { Aquadag } \\
\text { scaled to } \\
\text { Fullerene } \\
\text { Soot }\end{array}$ & $\begin{array}{c}\mathrm{PM}_{1} / \\
\text { EnCan-Total- } \\
900\end{array}$ & Nunavut, Canada & $\begin{array}{l}\text { From Mar } 2011 \\
\text { to Dec } 2013 \\
\text { remote site }\end{array}$ & 0.55 \\
\hline $\begin{array}{l}\text { Corbin et al. } \\
\text { (2019) }\end{array}$ & $\begin{array}{l}\text { Fullerene } \\
\text { Soot }\end{array}$ & $\begin{array}{c}\mathrm{PM}_{1} / \\
\text { IMPROVE-A } \\
\text { (washed) }\end{array}$ & - & $\begin{array}{l}\text { Chamber study - } \\
\text { four-stroke ship } \\
\text { diesel engine }\end{array}$ & $1.03 *$ \\
\hline $\begin{array}{l}\text { Laborde et al. } \\
\text { (2012b) }\end{array}$ & $\begin{array}{l}\text { Fullerene } \\
\text { Soot }\end{array}$ & NIOSH-5040 & - & $\begin{array}{c}\text { Chamber study - } \\
\text { CAST soot }\end{array}$ & $1.10^{*}$ \\
\hline
\end{tabular}




\section{Figures SI}

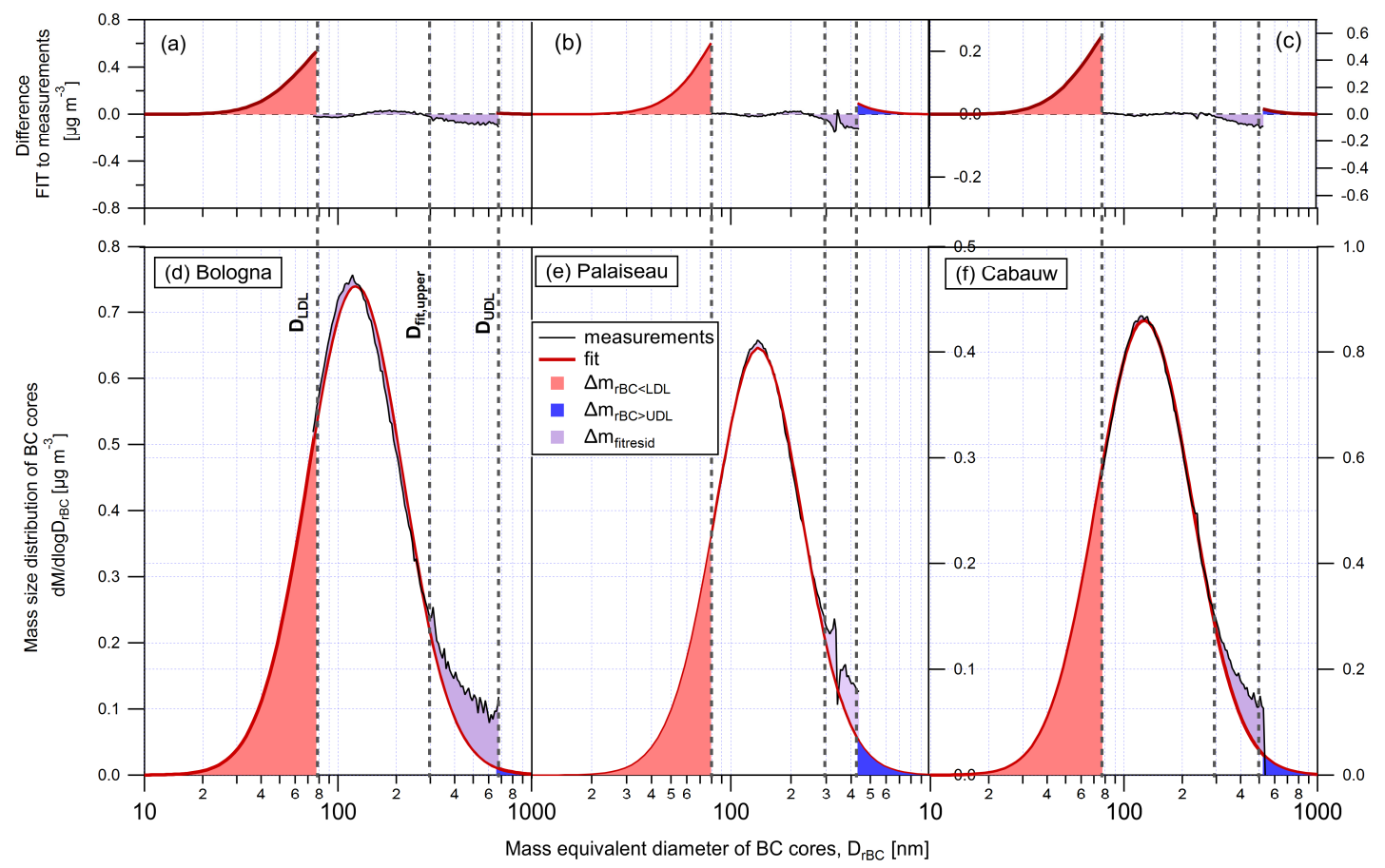

Figure S1: Approach to correct for the $\mathrm{rBC}$ mass outside the $\mathrm{rBC}$ core size range covered by the SP2 for the Bologna (panels a and d), the Palaiseau (panels b and e) and the Cabauw (panels c and f) campaigns. The bottom three panels show the measured $\mathrm{rBC}$ mass size distribution as a function of $\mathrm{rBC}$ core mass equivalent diameter,

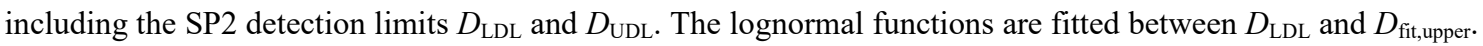

110 The integrated area of the red, purple, and blue shadings correspond to $\Delta m_{\mathrm{rB}, \angle L D L}, \Delta m_{\text {fitresid }}$ and $\Delta m_{\mathrm{rBC}>U D L}$, respectively (see Sect. 2.3.5). The top three panels additionally show the same shadings after subtraction of the measured size distribution (and measurement forced to be zero outside the SP2 detection range). 

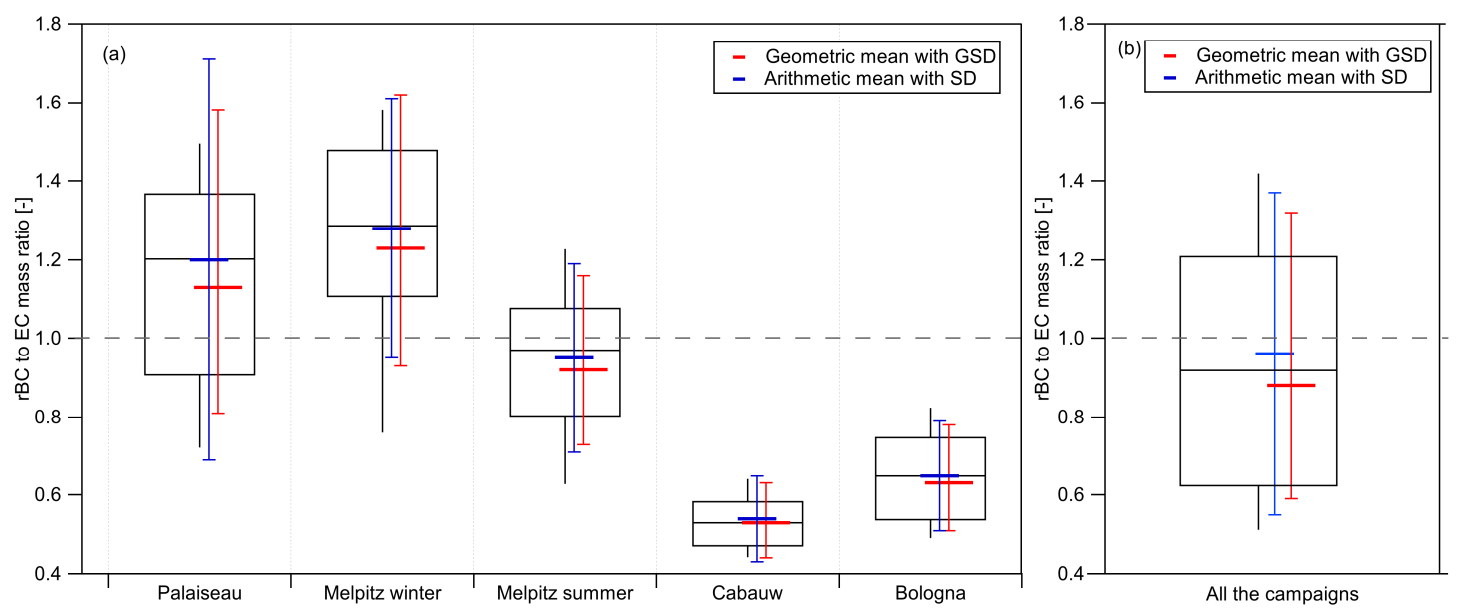

115 Figure S2: Statistics $\left(10^{\text {th }}, 25^{\text {th }}, 50^{\text {th }}, 75^{\text {th }}\right.$ and $90^{\text {th }}$ percentiles, arithmetic and geometric means, SD and GSD) of the $\mathrm{rBC}$ to EC mass ratio $\left(m_{\mathrm{rBC}} / m_{\mathrm{EC}}\right)$ per campaign (panel a) and with all the campaigns of this work (panel b).

120
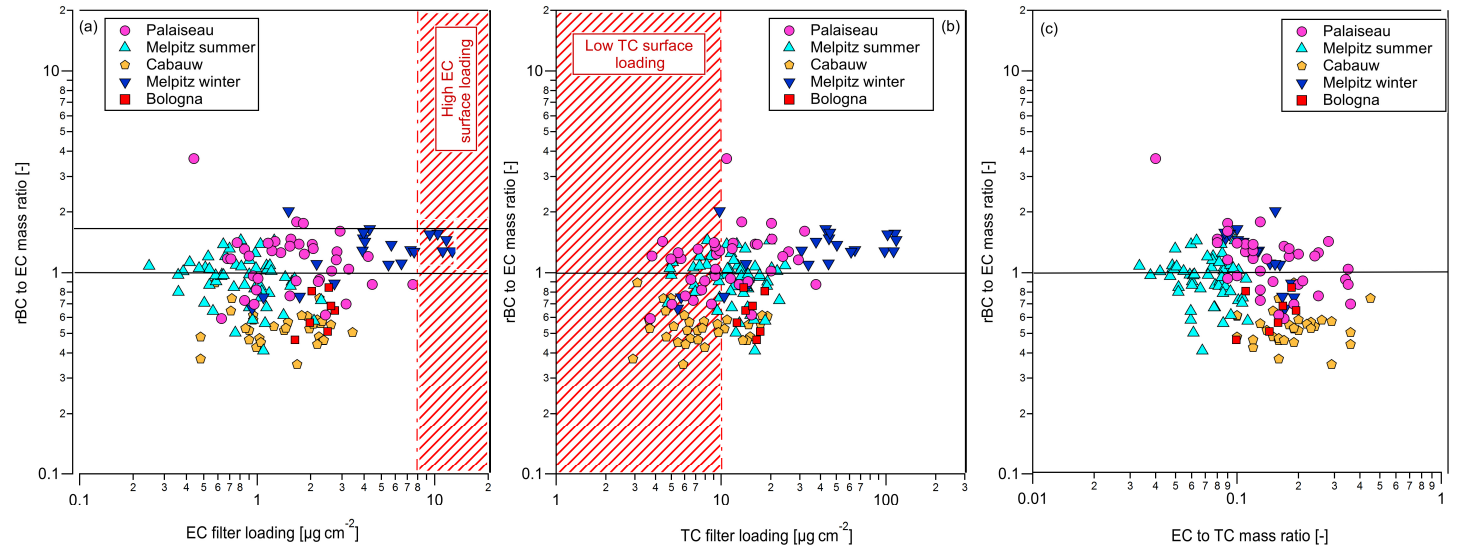

Figure S3: rBC mass concentration versus EC filter loading (panel a), TC filter loading (panel b) and EC/TC mass ratio (panel c). The red shaded areas in panel (a) and (b) indicate the high EC surface loading and the low TC surface loading areas respectively. 


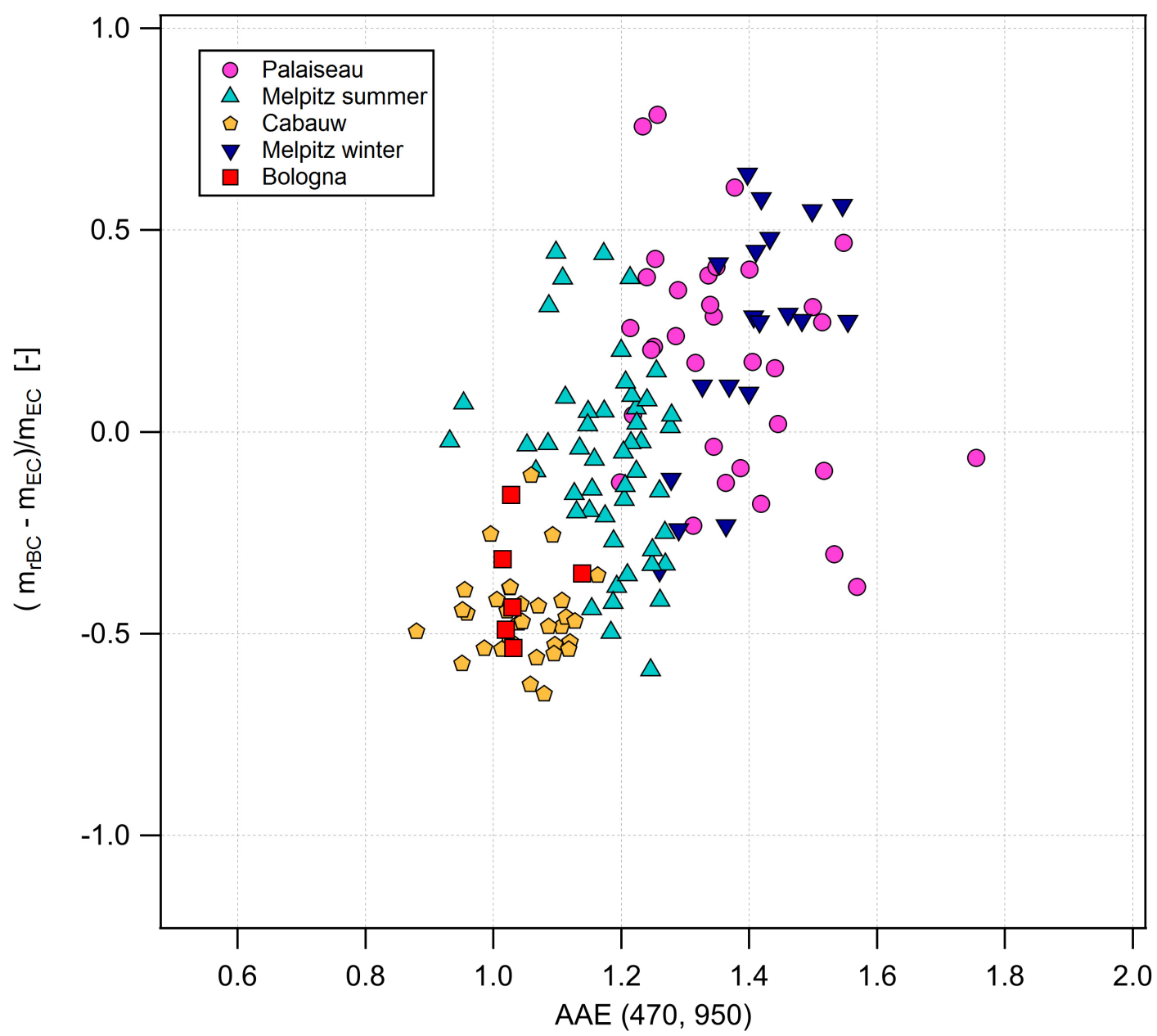

Figure S4: Relative difference between $m_{\mathrm{rBC}}$ and $m_{\mathrm{EC}}$ versus the AAE(470,950) coloured by campaign. 